\title{
Workload of nurses: observational study of indirect care activities/interventions
}

Carga de trabalho de enfermeiros: estudo observacional de atividades/intervenções de cuidados indiretos Carga de trabajo de enfermeros: estudio observacional de actividades/intervenciones de cuidados indirectos

\section{Mariana Santos de Campos', Bruna Andrade de Oliveira', Marcia Galan Perroca'}

'Faculdade de Medicina de São José do Rio Preto, Graduate in Nursing. São José do Rio Preto, São Paulo, Brazil.

\section{How to cite this article:}

Campos MS, Oliveira BA, Perroca MG. Workload of nurses: observational study of indirect care activities/interventions. Rev Bras Enferm [Internet]. 2018;71(2):297-305. DOI: http://dx.doi.org/10.1590/0034-7167-2016-0561

\section{Submission: 10-20-2016 Approval: 04-11-2017}

\begin{abstract}
Objective: Observe the workflow of nurses in hospitalization units identifying indirect care activities/interventions; measure the frequency and average time spent in performing them; and to verify the associations between average time of the activities interventions grouped into categories and per hospitalization unit. Method: Observational exploratory study using the timed technique. It was conducted in medical, surgical and specialized clinic units of a teaching hospital in the northwest of São Paulo Brazil, with 16 attending nurses as participants. Results: 90 hours of observation were performed, of which $58 \%$ ( 52 hours and 10 minutes) were related to indirect care activities of the patients. The most frequent activities/interventions were: "Communication" - 1,852 (44.1\%), mean 34.6 (SD = 54); “Walking” - 1,023 (24.3\%), mean 22 (SD = 49.2); and "Documentation" - $663(15.8 \%)$, mean $82.7(S D=144.4)$. Conclusion: These findings favor a redesign of the work process and foster the need to update and refine the current workload measurement instruments.
\end{abstract}

Descriptors: Workload; Nursing care; Nursing; Time Management; Nursing Human Resources in Hospitals.

\section{RESUMO}

Objetivos: Observar o fluxo de trabalho de enfermeiros em unidades de internação identificando atividades/intervenções de cuidado indireto; mensurar a frequência e o tempo médio despendido na realização das mesmas; e verificar as associações entre o tempo médio das atividades/intervenções agrupadas em categorias e por unidade de internação. Método: Estudo exploratório observacional utilizando a técnica de tempos cronometrados. Foi conduzido em unidades de clínica médica, cirúrgica e especializada de um hospital de ensino do noroeste paulista, tendo como participantes 16 enfermeiros assistenciais. Resultados: Foram realizadas 90 horas de observação, sendo 58\% (52 horas e 10 minutos) referentes às atividades de cuidado indireto ao paciente. As atividades/intervenções mais executadas constituíram-se em: "Comunicação" - 1.852 (44,1\%), média 34,6 ( $\mathrm{DP}=54)$; "Deslocamento" - $1.023(24,3 \%)$, média 22 ( $\mathrm{DP}=49,2)$; e "Documentação" - 663 (15,8\%), média $82,7(\mathrm{DP}=144,4)$. Conclusão: Esses achados favorecem o redesenho do processo de trabalho e fomentam a necessidade de atualização e refinamento dos instrumentos de mensuração de carga de trabalho atuais.

Descritores: Carga de Trabalho; Cuidados de Enfermagem; Enfermagem; Gerenciamento do Tempo; Recursos Humanos de Enfermagem no Hospital.

\section{RESUMEN}

Objetivo: Observar el flujo de trabajo de enfermeros en unidades de internación identificando actividades/intervenciones de cuidado indirecto; medir frecuencia y tiempo promedio empleado en realizar dichas tareas; y verificar las asociaciones entre tiempo promedio de actividades/intervenciones agrupadas en categorías y por unidad de internación. Método: Estudio exploratorio, observacional, utilizando técnica de tiempos cronometrados. Realizada en unidades de clínica médica, quirúrgica y especializada de hospital de enseñanza del noroeste paulista, habiendo participado 16 enfermeros asistenciales. Resultados: Totalizadas 90 horas de observación, siendo 58\% (52 horas 10 minutos) referentes a las actividades de cuidado indirecto al paciente. Las actividades/intervenciones más ejecutadas resultaron: "Comunicación" - $1.852(44,1 \%)$, media 34,6 (SD = 54); "Traslado" - $1.023(24,3 \%)$, media $22(\mathrm{SD}=49,2)$ y "Documentación" - $663(15,8 \%)$, media 82,7 (SD =144,4). Conclusión: 
Los hallazgos favorecen el rediseño del proceso de trabajo y promueven la necesidad de actualización y redefinición de los instrumentos de medición de carga de trabajo actuales.

Descriptores: Carga de Trabajo; Atención de Enfermería; Administración del Tiempo; Personal de Enfermería en Hospital.

CORRESPNDING AUTHORＭariana Santos de Campos E-mail: maacampos94@gmail.com

\section{INTRODUCTION}

Workload can be understood as all activities performed in a given period by the nursing team in the care process and the time spent to perform these actions ${ }^{(1)}$. However, the activities it encompasses have been understood in various forms ${ }^{(2)}$.

For many years, it was considered to be related only to direct care (performed in the presence of the patient) and indirect activities (occurring outside the nurse-patient interaction) (2). More recently, the concept of indirect care activities has been expanded to include management of an environment of interdisciplinary care and collaboration ${ }^{(3)}$.

The Patient Classification Instrument $(\mathrm{PCI})$, an integral part of the Patient Classification System (SCP), identifies the patients' individual needs and groups them into categories, allowing them to determine their degree of complexity and define the care profile ${ }^{(4)}$. These instruments have been developed in several specialties to assist in the management of care. In this concept, it is possible to calculate the workload and time required for the care process, by considering the actual needs of the client/user's care ${ }^{(4)}$. Thus, the $\mathrm{PCl}$ has been used to measure the workload of the nursing team.

Studies measuring the time spent by nurses in performing their activities in different practice scenarios indicate a predominance of time consumed in indirect care activities, ranging from $43.2 \%{ }^{(5)}$ to $55.7 \%{ }^{(6)}$. However, most PCls address direct care activities. The planning and coordination of the caring process, which includes communication with nursing professionals and other areas, as well as documentation, were included only in a Brazilian classification instrument ${ }^{(4)}$.

Dissatisfaction among the professionals related to the overload of work in the units ${ }^{(7-9)}$ and the recognition by researchers $^{(7,10-11)}$ that the work involved in nursing is not confined to some activities of the caring process (medications, etc.), but also to a series of indirect activities (collaboration with staff, other professionals and students, among others) has generated reflection and the need to build instruments that can capture more faithfully the work of nurses, notably PCls. It is important to point out, however, the impossibility of an instrument that contains all the activities carried out, because at all times the nursing staff faces numerous unforeseeable situations. Thus, they address those that present greater relevance in daily practice p $^{(7,11)}$.

Few studies have been conducted to identify activities that directly influence the workload. Some factors were considered influential, however, difficult to measure ${ }^{(7-8,10-11)}$. Thus, this study was based around the following questions: Which activities/ interventions related to the indirect care of the patient are carried out by the care providing nurses in hospitalization units?; What is the mean time spent on each of these?; and Are there associations between the mean time of activities/interventions grouped into categories and per hospitalization unit?

\section{OBJECTIVE}

To observe the workflow of nurses in hospitalization units, identifying indirect care activities/interventions and measure the frequency and average time spent in performing these;

Verify the associations between mean time of activities/interventions grouped into categories and per hospitalization unit.

\section{METHOD}

\section{Ethical aspects}

The professionals received orientation about the purpose of the study and the voluntary nature of their participation and signed the Term of Free and Informed Consent. The study was approved by the Research Ethics Committee of the institution where the study took place.

\section{Design, place of study and period}

This study was observational exploratory with structured method. Structured observational methods are data collection techniques in which observational events or behaviors are selected in advance with the preparation of forms and types of activities that the observer should consider ${ }^{(12)}$.

Two hospitalization units of a medical clinic, two surgical clinics and one specialized (Infectious Diseases) clinic of a teaching hospital located in the northwest of São Paulo constituted the study scenario. The study was carried out in March and April 2015.

\section{Study population}

All nurses $(n=16)$ were observed in the units investigated. The measurement of the time totaled 90 hours, excluding the time dedicated to the pre-test. It is important to emphasize that nursing activities are characterized by their short duration (30 seconds to one minute) and successive alternation ${ }^{(8)}$. Direct observation studies are considered exhaustive and therefore include less sampling. International investigations have reported observation time varying from 85.2 hours $^{(7)}$ to 98.2 hours $^{(8)}$ as significant to identify the wide range of nursing activities.

\section{Study Protocol}

The research was conducted in the following steps:

Mapping of activities/indirect care interventions - Initially, direct observation was performed with nurses working day and night shifts during their activities for a period of three days. This preliminary observation generated a preliminary listing that was later complemented with indirect care activities/ 
interventions described in the Nursing Intervention Classification (NIC) $)^{(3)}$ and also by results of various studies ${ }^{(7-8,10-11,13)}$. The NIC taxonomy has been used since 1992 to standardize language in nursing. It groups 554 interventions and more than 12 thousand related activities based on clinical practice and research results ${ }^{(3)}$. Because the work of the nursing team is standardized, researchers have used this taxonomy to conduct studies on workload measurement ${ }^{(14-15)}$. Subsequently, a final listing was constructed, triangulating the three different forms of data collection with the interventions and their respective activities described in the NIC and non-NIC activities.

Pre-test - The final list constructed was entered into software and tested by one of the researchers after orientation and training in the investigated units, in order to evaluate the representativeness and relevance of the mapped activities. At that time, a need was identified for the addition or exclusion of any activities.

Measurement of Time Spent - The time and movement technique $^{(16)}$ was used by means of specific time tracking software ${ }^{(17)}$ called Togg|(18). The mapped interventions and their respective activities described in the NIC and the activities not described in this taxonomy were inserted in the software using a portable computer. With each intervention observed, the listing expanded with related activities. After the selection corresponding to the moment, the "start" button was pressed and the stopwatch was activated, it was then returned to zero ("stop" button) at its end. In case of interruption of work continuity, the timer was interrupted and triggered again when the nurse resumed the activity being measured. The stop watch was chosen because it presents advantages in relation to the work sample, since it provides details of the workflow and its sequence, avoiding loss of information regarding activities with a short duration ${ }^{(8)}$.

The direct observation was carried out by two researchers from Monday to Sunday, including the various work shifts (morning, afternoon and night). Each field observer accompanied a professional, for a minimum of three times, in sessions lasting from three to four hours. Inter-rater reliability test was conducted to verify compatibility in the activities/interventions recorded, obtaining a 95\% agreement index.

\section{Analysis of results and statistics}

Descriptive statistics were used with calculation of frequencies, percentages, means, standard deviation, medians and interquartile range $(\mathrm{IQR}=\mathrm{Q} 3-\mathrm{Q} 1)$. We chose to present the data in seconds due to the short time of most activities. To evaluate the difference between mean times, we used the Analysis of Variance (ANOVA) and Tukey's post-test. The analysis was performed using the Statsdirect program version1,9,15. The level of significance was set at 0.05 .

\section{RESULTS}

Sixteen nurses participated in the study (six in the medical clinic, seven in the surgical and three in the specialized clinic) with a predominance of females $(n=13)$, mean age 37.2 years $(\mathrm{SD}=10.6$, range $25-59$ years) and mean time of professional performance 6.1 years $(S D=7.6$, variation 2 months to 25 years).
A total of 90 hours of observation were performed, with $58 \%$ (52 hours and 10 minutes) referring to the activities/interventions of indirect care to the patient, distributed between the medical clinic units (18 hours and 39 minutes), surgical (23 hours and 22 minutes) and infectious and parasitic diseases (IPD) (10 hours and eight minutes). The remaining hours, 42\% (37 hours and 49 minutes), were related to direct, associated and personal care activities - the detailing of which was not the objective of this study.

The previous listing consisted of 16 interventions and 46 indirect care activities. After the pre-test, we excluded technological control, verification of controlled substances and interpretation of laboratory data, since such interventions were not observed in the daily practice of nurses. The final listing included 13 NIC interventions and their unfolding into 43 activities plus an additional three activities not described in the NIC, namely - Communication, Walking, and Waiting Time. Communication was added to include verbal contacts with the nursing team, other members of the health team, support services and telephone calls, among others, not included in the intervention "Support to the doctor" and "Exchange of health information". Walking (going from one place to another inside and/or outside the unit) and waiting time (time waiting for materials, medicines and others for performing procedures). It is underscored that these constitute activities mentioned in international time measurement studies ${ }^{(7-8)}$.

We identified 4,202 observations of the activities performed by the nurse. The description of the interventions and activities investigated described in the NIC are presented in Chart 1.

The frequency of interventions/activity ranged from 5 $(0.1 \%)$ for preceptor employee to $1,852(44.1 \%)$ for communication, and the mean time spent was 22 seconds $(\mathrm{SD}=$ 49.2) for staff transference within and out of the unit at 245.1 seconds ( $\mathrm{SD}=269.8$ ) for change in work shift (see Table 1).

For statistical analysis, non-NIC interventions and activities were grouped into five categories in order to verify their associations. They were: 1. COMMUNICATION: communication, shift, exchange information care Health; 2. DOCUMENTATION; 3. SUPERVISION: of employees, preceptor: student, preceptor: staff member, delegation, mediation of conflicts; 4. CONTROLS: sample for exams, supplies, environment, check crash cart, support the doctor; and 5. WALKING; and waiting time.

Table 2 shows that the frequency of categories ranged from 185 (Supervision) to 1,929 (Communication). Statistical differences were observed by ANOVA ( $p \leq 0.05$ ) between the mean time spent in the different categories, except for Communication $\times$ Controls $(p=0.66)$ and Documentation $\times$ Supervision $(p=0.91)$ (Table 2$)$.

The differences between the mean time spent on each of the five categories per hospitalization unit investigated are shown in Table 4. The frequency ranged from 51 for Supervision in the medical clinic to 871 for Communication in the surgical clinic, and the $p$ value ranged from 0.14 to 0.67 (ANOVA).

Among the activities, the 15 performed most in the study units were selected, and are presented in Table 4. These were constituted in: Communication with the Nursing team - 1,075 $(28.4 \%)$; and Walking in the hospitalization unit - 1,001 $(26.4 \%)$. In relation to the time spent, greater values were found for change-in-shift 245.1 seconds $(\mathrm{SD}=269.8)$ and to perform daily nursing and/or SNC-126.5 (SD = 207.7). 
Chart 1 - Description of interventions and activities investigated as described in the Nursing Intervention Classification (NIC), São José do Rio Preto, São Paulo, Brazil, 2015

\begin{tabular}{|c|c|c|}
\hline Interventions & Definition & Related activities \\
\hline Support for doctor & Collaborating with doctors to provide qualified care & Discuss clinical case with physician \\
\hline $\begin{array}{l}\text { Control Sample for } \\
\text { Examinations }\end{array}$ & $\begin{array}{l}\text { Sample collection, preparation and preservation, } \\
\text { laboratory examination }\end{array}$ & $\begin{array}{l}\text { Identify material for examination } \\
\text { Packaging test material }\end{array}$ \\
\hline $\begin{array}{l}\text { Supply Chain } \\
\text { Management }\end{array}$ & $\begin{array}{l}\text { Acquisition and maintenance of items appropriate for the } \\
\text { provision of care }\end{array}$ & $\begin{array}{l}\text { Receiving / checking material and medication } \\
\text { Preparation of medication } \\
\text { Check the medicine fridge } \\
\text { Request Repair / Replacement Parts } \\
\text { Request materials and medications } \\
\text { Evaluate material quantity in unit } \\
\text { Check equipment operation } \\
\text { Return of medicines } \\
\text { Organize material for procedure }\end{array}$ \\
\hline $\begin{array}{l}\text { Environmental } \\
\text { Control }\end{array}$ & $\begin{array}{l}\text { Management of the environment around the patient } \\
\text { aiming for therapeutic benefit, sensorial appeal and } \\
\text { psychological well-being }\end{array}$ & $\begin{array}{l}\text { Allocate stretchers in the hallway } \\
\text { Organize clothes closet } \\
\text { Organize environment } \\
\text { Remove materials for cleaning } \\
\text { Request cleaning service }\end{array}$ \\
\hline Delegation & $\begin{array}{l}\text { Transfer of responsibility for patient care, while } \\
\text { maintaining accountability for results }\end{array}$ & $\begin{array}{l}\text { Request referral of patient to a surgical center, } \\
\text { examination or ICU } \\
\text { Guide drug administration, examination, surgery, } \\
\text { examination and dressing } \\
\text { Check the testing of NT/NA } \\
\text { Distribute daily schedule of services }\end{array}$ \\
\hline Documentation & Registering pertinent patient data in clinical records & $\begin{array}{l}\text { Perform daily annotations and/or SNC } \\
\text { Write summary in shift book } \\
\text { Check medical / nursing prescription } \\
\text { Register patient admission / discharge } \\
\text { Record transfer / death of the patient } \\
\text { Fill in the HICC control form } \\
\text { Organizing nursing evolutions } \\
\text { Prepare home visit authorization } \\
\text { Reformulating documents of the unit }\end{array}$ \\
\hline $\begin{array}{l}\text { Mediation of } \\
\text { conflicts }\end{array}$ & $\begin{array}{l}\text { Constructive dialogue, aiming at the resolution of } \\
\text { controversies }\end{array}$ & $\begin{array}{l}\text { Mediating conflicts between patient / family and / or } \\
\text { nursing team }\end{array}$ \\
\hline Change-in-shift & Information exchange on change in shift & Pass on and take over shift \\
\hline Preceptor: Student & Support / learning support & Accompany/guide undergraduate trainee \\
\hline Preceptor: Employee & Assistance, support and planned guidance to new employee & Accompany/guide newly admitted staff member in unit \\
\hline $\begin{array}{l}\text { Information exchange } \\
\text { on health care }\end{array}$ & Providing information to patient and other professionals & $\begin{array}{l}\text { Receive on-call staff from other units } \\
\text { Discuss case with other professionals }\end{array}$ \\
\hline Crash Cart Check & Content review and maintenance & Check Crash cart \\
\hline
\end{tabular}

Note: ICU Intensive Care Unit; Nursing Technician/Nursing Assistant - NT NA; Systematization of Nursing Care - SNC; Hospital Infection Control Committee - HICC

Table 1 - Relative frequency and mean time spent (in seconds) on the interventions / activities of indirect care to the patient, São José do Rio Preto, São Paulo, Brazil, 2015

\begin{tabular}{|c|c|c|c|c|}
\hline Activities/Interventions & $F(\%)$ & Median (Interquartile Range) & Mean (Standard Deviation) & Variation \\
\hline Support for doctor & $44(1.0)$ & $48(74.5)$ & $72.9(90.8)$ & $2-512$ \\
\hline Communication* & $1.852(44.1)$ & $20(30)$ & $34.6(54)$ & $27-1.355$ \\
\hline Control Sample for Examinations & $41(1.0)$ & $24(31)$ & $31.7(32.4)$ & $2-186$ \\
\hline Supply Chain Management & $141(3.4)$ & $37(40)$ & $50.1(61.7)$ & $1-456$ \\
\hline Environmental Control & $142(3.4)$ & $19.5(23.2)$ & $38.4(82.7)$ & $1-684$ \\
\hline Delegation & $49(1.2)$ & $28(32)$ & $34.1(22.6)$ & $4-106$ \\
\hline Walking* & $1.023(24.3)$ & $12(17)$ & $22(49.2)$ & $1-789$ \\
\hline Documentation & $663(15.8)$ & $41(73)$ & $82.7(144.4)$ & $1-1.383$ \\
\hline Mediation of conflicts & $8(0.2)$ & $54(75.2)$ & 102(140.8) & $17-442$ \\
\hline
\end{tabular}




\begin{tabular}{|c|c|c|c|c|}
\hline Activities/Interventions & $F(\%)$ & Median (Interquartile Range) & Mean (Standard Deviation) & Variation \\
\hline Change in work shift & $47(1.1)$ & 128(320) & $245.1(269.8)$ & $4-1.316$ \\
\hline Preceptor: student & $51(1.2)$ & 19(54) & $44.4(70.5)$ & $1-426$ \\
\hline Preceptor: employee & $5(0.1)$ & $42(252.5)$ & 133(179) & $17-446$ \\
\hline Employee supervision & $72(1.7)$ & $55.5(111.2)$ & 121.1(192.9) & $1-1.132$ \\
\hline Waiting time ${ }^{*}$ & $25(0.6)$ & 19(42) & 43.8(60.1) & $2-270$ \\
\hline Information exchange on health care & $30(0.7)$ & $35(60.7)$ & $55.8(46.1)$ & $9-179$ \\
\hline Emergency Cart Check & $9(0.2)$ & 28(69) & $70.2(100.1)$ & $8-324$ \\
\hline
\end{tabular}

Note: * Activities described in time measurement studies ${ }^{(8,11-13,15)}$

Table 2 - Descriptive and Variance Analysis (ANOVA) among the categories Communication, Documentation, Supervision, Controls and Walking, São José do Rio Preto, São Paulo, Brazil, 2015

\begin{tabular}{|c|c|c|c|c|c|}
\hline Categories & Communication & Documentation & Supervision & Controls & Walking \\
\hline Communication & - & $p<0.01$ & $p<0.01$ & $p=0.66$ & $p<0.01$ \\
\hline Frequency & 1.929 & & & & \\
\hline Variation & $27-1.355$ & & & & \\
\hline $\mathrm{M}(\mathrm{SD})$ & $40.1(75)$ & & & & \\
\hline$M d(I Q R)$ & $22(33)$ & & & & \\
\hline Documentation & $p<0.01$ & - & $p=0.91$ & $p<0.01$ & $p<0.01$ \\
\hline Frequency & & 663 & & & \\
\hline Variation & & $1-1.383$ & & & \\
\hline$M(S D)$ & & $82.7(144.4)$ & & & \\
\hline$M d(I Q R)$ & & $41(73)$ & & & \\
\hline Supervision & $p<0.01$ & $p=0.91$ & - & $p<0.01$ & $p<0.01$ \\
\hline Frequency & & & 185 & & \\
\hline Variation & & & $1-1.132$ & & \\
\hline $\mathrm{M}(\mathrm{SD})$ & & & $76.4(137.7)$ & & \\
\hline$M d(I Q R)$ & & & $33(65)$ & & \\
\hline Controls & $p=0.66$ & $p<0.01$ & $p<0.01$ & - & $p<0.01$ \\
\hline Frequency & & & & 377 & \\
\hline Variation & & & & $1-684$ & \\
\hline$M(S D)$ & & & & $46.8(73.5)$ & \\
\hline$M d(I Q R)$ & & & & 28(39) & \\
\hline Walking & $p<0.01$ & $p<0.01$ & $p<0.01$ & $p<0.01$ & - \\
\hline Frequency & & & & & 1.048 \\
\hline Variation & & & & & $1-789$ \\
\hline$M(S D)$ & & & & & $22.5(49.5)$ \\
\hline$M d(I Q R)$ & & & & & $12(17.7)$ \\
\hline
\end{tabular}

Note: M(SD) - Mean (Standard Deviation); Md(IQR) - Median (Inter Quartile Range)

Table 3 - Relative frequency and mean time spent (in seconds) in the five categories analyzed, according to the hospitalization unit (ANOVA), São José do Rio Preto, São Paulo, Brazil, 2015

\begin{tabular}{|c|c|c|c|c|c|c|c|c|c|c|}
\hline \multirow{2}{*}{ Categories } & \multicolumn{3}{|c|}{ Medical clinic } & \multicolumn{3}{|c|}{ Surgical Clinic } & \multicolumn{3}{|c|}{ IDP } & \multirow{2}{*}{$p$} \\
\hline & $F$ & $\mathrm{M}(\mathrm{SD})$ & $M d(I Q R)$ & $\mathbf{F}$ & $M(D P)$ & Md(AIQ) & $F$ & $M(S D)$ & Md(IQR) & \\
\hline Communication & 727 & $39(73.5)$ & $19(32)$ & 871 & $39.8(69.6)$ & $22(32)$ & 330 & 43.3(90.7) & $25(34.2)$ & 0.67 \\
\hline Documentation & 242 & $88.3(153.9)$ & $41.5(78.5)$ & 345 & 83.8(149.8) & 42(69.7) & 75 & $60.8(65.2)$ & $37(61)$ & 0.34 \\
\hline Supervision & 51 & 72.1(106.7) & 28(85) & 77 & $60.3(112.2)$ & $32(43)$ & 57 & $102(184.3)$ & $40(82)$ & 0.21 \\
\hline Controls & 162 & 40.1(59.7) & $21(38)$ & 97 & $47.4(65.7)$ & $32(35.5)$ & 117 & 56(93.9) & $31(37.5)$ & 0.19 \\
\hline Walking & 340 & $21.6(57.1)$ & $10(11)$ & 512 & $20.8(42.4)$ & $12.5(18)$ & 196 & $28.7(52.2)$ & 18(18) & 0.14 \\
\hline
\end{tabular}

Note: IDP - Infectious and Parasitic Diseases; M(SD) - Mean (Standard Deviation); Md(IQR) - Median (Inter Quartile Range) 
Table 4 - Indirect patient care activities performed most by nurses and average time spent (in seconds), São José do Rio Preto, São Paulo, Brazil, 2015

\begin{tabular}{|c|c|c|c|c|c|}
\hline Activities & $F(\%)$ & Total (hours) & $M d(I Q R)$ & $M(S D)$ & Variation \\
\hline Communication with nursing team & $1,075(28.4)$ & $08: 39$ & $18(27)$ & $29.1(37.8)$ & $1-572$ \\
\hline Walking within unit & $1,001(26.4)$ & $05: 22$ & $12(16)$ & $19.3(38.7)$ & $1-789$ \\
\hline Communication by telephone & $317(8.4)$ & 05:01 & $38(47)$ & $57(59.4)$ & $2-501$ \\
\hline Realize annotation and/or SNC & $238(6.3)$ & $08: 21$ & $57(106.5)$ & $126.5(207.7)$ & $1-1.383$ \\
\hline Register change in shift & $230(6.1)$ & 03:10 & $30(44.7)$ & 49.6(62.8) & $1-413$ \\
\hline Communication with medical team & $210(5.5)$ & 01:58 & $18(28.7)$ & $33.9(50.2)$ & $2-351$ \\
\hline Communication with support services & $166(4.4)$ & $01: 26$ & $15(23.7)$ & $32.5(106.8)$ & $2-1.355$ \\
\hline Register admission or discharge & $117(3.1)$ & 02:20 & $52(73)$ & $71.9(6.6)$ & $1-364$ \\
\hline Communication with health team & 113(3.0) & $00: 36$ & $14(22)$ & 28(41.8) & $2-286$ \\
\hline Organize ambient & $87(2.3)$ & 01:01 & $18(25)$ & $39.9(91.4)$ & $1-684$ \\
\hline Accompany/guide students & $51(1.3)$ & $00: 37$ & $19(52.5)$ & $44.4(70.5)$ & $1-426$ \\
\hline Evaluate/alter monthly duty roster & $50(1.3)$ & $01: 38$ & $54(108)$ & 118.3(173.8) & $1-775$ \\
\hline Change-of-shift nursing report & $47(1.2)$ & 03:12 & $128(276.5)$ & 245.1(269.8) & $4-1.316$ \\
\hline Guidance (procedures, exams, surgery) & $44(1.2)$ & $00: 23$ & $26.5(24)$ & $31.6(21.9)$ & 4-106 \\
\hline Order material medications & $40(1.1)$ & $00: 38$ & $52(42.5)$ & $58.2(39.6)$ & $1-157$ \\
\hline
\end{tabular}

Note: M(SD) - Mean (Standard Deviation); Md(IQR) - Median (Inter Quartile Range); Systematization of Nursing care -SNC

\section{DISCUSSION}

The findings of this study showed that $58 \%$ of the 90 hours observed were spent by nurses performing activities/interventions of indirect care. Previous studies have shown that nurses spend less time in these activities in units with similar characteristics to this study: medical clinic, $47.3 \%{ }^{(19)}$; medical-surgical, $50 \%{ }^{(20)}$; and surgical $55.7 \%{ }^{(6)}$. Also, in others with divergent care profile and work dynamics: joint housing, 31\%(21); emergency unit, $35 \%{ }^{(22)}$; and oncology outpatient clinic, $43.2 \%{ }^{(5)}$.

It was verified that $13(81.3 \%)$ of the interventions categorized in the NIC consumed 27 hours and 44 minutes of the time spent by the nurse, while the other three activities (18.7\%) not described in this taxonomy consumed 24 hours and 26 minutes. It was observed that the latter are related to communication, walking and waiting time and represented $46.2 \%$ of the total time.

In the various NIC interventions and non-NIC activities, the ones that most occupied the nurses' working time were: Communication (44\%, 17 hours and 51 minutes), Walking $(24.3 \%$, 6 hours and 16 minutes) and Documentation 15.8\%, 15 hours and 14 minutes), totaling $84.2 \%$ and 39 hours and 19 minutes of the time spent. The remaining non-NIC interventions and activities accounted for $15.8 \%$ of the total, corresponding to 12 hours and 51 minutes. The lower percentiles and time spent on such interventions and activities may erroneously be attributed to a low degree of importance, however it is possible that this a list of shorter and more targeted activities ${ }^{(8)}$.

Within the Communication activity, the aspects considered were "Communication with the nursing team", "Medical team", "Other professionals of the health team", "Support services" and "Telephone communication". Two international investigations carried out in medical and surgical units showed the time spent by nurses with this activity $\left(12 \%{ }^{(8)}\right.$ and $\left.17.8 \%{ }^{(7)}\right)$ was lower than that found in the present study (44.1\%). This can be explained by the fact that the study site is a teaching hospital where there is a great flow of personnel and, consequently, intense communication with the multi-professional team. In addition, differences could arise because telephone communication was included, whereas in other studies ${ }^{(7-8)}$ this was considered separately or not at all.

The communication process favors effective and safe practice for the patient. However, the time spent in its accomplishment can be reduced so that the exchange of information within the team and between nursing and multi-professional teams is carried out in a way that avoids noise, interruptions and interference. Noise interferes with the concentration of those involved, favoring a loss of information or even forgetfulness ${ }^{(23-24)}$. Interruptions and interferences fragment or even render impossible the finalization of information transmission, thereby generating repetition ${ }^{(8,23)}$ and duplication of messages. Parallel conversations among professionals during the shift can also increase the time spent on this activity ${ }^{(24)}$.

After communication, "Walking" occupied the most time of the nurses, especially those in the hospitalization unit. This activity, although not listed in the NIC, has been reported in international studies with values of $17.1 \%{ }^{(7)}$ and $20.1 \%{ }^{(8)}$. Measurements showed that nurses cover 1.6 to $8 \mathrm{~km}$ per day shift of 10 hours ${ }^{(25)}$, i.e. from 160 to $800 \mathrm{~m} /$ hour. In this investigation, no statistically significant and consistent relationship was found between the various types of unit architecture and the time spent caring for patients. The authors suggest that the adaptability of nurses may have offset the limitations imposed by the unit's physical layout.

Clearly, the real need for Walking and the location of the materials and equipment used to perform the care should be further examined. An Australian study ${ }^{(26)}$ showed that the time spent in transit by nurses (time between activities and patient care), over a three-year investigation, showed a reduction from $7.4 \%$ to $4.6 \%$, after optimization strategies. 
Documentation ranked in third place in terms of interventions occupying nurses' time. Research on the subject presented values of $6.7 \%{ }^{(22)}, 11.3 \%{ }^{(8)}, 11.5 \%{ }^{(5)}$ and $18.4 \%{ }^{(20)}$. It is important to note that most of the mentioned studies ${ }^{(5,20,22)}$ used the method of work sampling rather than time tracking to measure the time.

It is known that documentation is extremely important for the professional practice of nurses, since it is used as a tool to search for information and also to exchange knowledge. However, the time consumed is significantly high, making it necessary to implement some strategies for its reduction, such as the implementation of electronic record keeping ${ }^{(27)}$. In the institutions that already use it, such as seen in the present study, it is possible to improve the use of computerized systems, by increasing the number of computers available for access $^{(28)}$, employing more investment to avoid system failures (inoperative system) and in order to train and continue education, given that some health professionals still show resistance and difficulty to handle this type of documentation ${ }^{(27)}$.

The mapping of 502 Nursing activities in North American hospitals ${ }^{(29)}$ identified 21 of these as commonly being considered by $90 \%$ of nursing managers for daily decision making on Nursing staff. These included four indirect care activities (documentation, health care information exchange, case management and change-in-shift). The high time taken to attend these interventions refers to the reflection on the variables that have been considered in the composition of the available PCls.

The findings showed that the average time spent on the activities/interventions when grouped (communication, documentation, supervision, controls and walking) were different, except between Communication $\times$ Controls and Documentation $\times$ Supervision. Still, they pointed out that the mean times did not differ among investigated units (range from $p=0.14$ to $p=0.67$ ).

It was observed that some activities, although they occupy more time, occur less frequently and vice versa. Others registered higher frequency and more time, such as "Communication with the nursing team" - 1,073 (28.7\%, 8 hours and 39 minutes); "Walking in the hospitalization unit" - 1,001 (26.7\%, 5 hours and 22 minutes) and "Telephone communication" - 317 (8.5\%, 5 hours and 1 minute). There were also other activities that occupied significant time, but presented a lower frequency, such as: "Change-in-shift" - 47 (1.2\%, 3 hours and 12 minutes) and "Register admission and discharge of the patient" - 117 (3.1\%, 2 hours and 20 minutes).

The time spent conducting each activity was often short, lasting merely seconds. It was noted that, frequently, there was no effective termination of the task, since another activity had to be initiated or interrupted. This situation was also reported in other studies $^{(7-8)}$ in which nurses spent less than 30 seconds on some activities; in addition, these professionals spent $34 \%$ of their time on multitasking ${ }^{(30)}$, which clearly demonstrates the intense routine of these professionals. Also, the constant interruptions experienced by nurses during their workflow can explain the high variability in the recorded times as revealed in the standard deviations ${ }^{(8)}$.

It is worth noting that the variations in time spent to carry out the interventions is significantly lower than the times estimated by the NIC taxonomy ${ }^{(3)}$, with the exception of "Documentation", which presented a variation from 1 second to 23 minutes (1,383 seconds), i.e. values higher than those described as 15 minutes. It should be noted that the time estimated by this taxonomy was also higher than that found in national(22) and international units ${ }^{(7-8)}$.

\section{Limitations of the study}

The indirect care activities and the average times found in this study reflect the workflow of nurses in a specific care setting and are limited to the time of observation.

\section{Contributions to the area of Nursing, health or public policy}

Investigations into how health professionals occupy their time make it possible to redesign the work process in the units, thereby eliminating or minimizing activities/time that do not add value, in turn generating greater efficiency in the nurses' work. Furthermore, they contribute to a better understanding of the components of the nursing workload and to planning the personnel needed to meet the demand for patient care. It is also worth noting that the mapping of activities/interventions carried out by the nursing team provides greater visibility of the professional work by identifying activities that are not valorized, but are fundamental for the continuity of care, thus enabling negotiations for changes in the nursing practice scenario.

\section{CONCLUSION}

The identification of activities/interventions of indirect care verified, sequentially, "Communication", "Walking" and "Documentation" as those that most consume nurses' working time. These findings foster the need for organizational changes and optimizing the work process, introduction of new technological strategies, and updating and refinement of current workload measurement instruments, particularly the PCls.

\section{FUNDING}

Study financed by the Fundação de Amparo à Pesquisa do Estado de São Paulo (FAPESP).

\section{REFERENCES}

1. Berry L, Curry P. The nursing workload and patient care. Canadian Federation of Nurses Unions (CFNU) Report [Internet]. 2012 [cited 2016 Oct 15]. Available from: https://nursesunions.ca/sites/default/files/cfnu_workload_paper_pdf.pdf

2. Alghamdi MG. Nursing workload: a concept analysis. J Nurs Manag [Internet]. 2016[cited 2016 Oct 10];24(4):449-57. Available from: http://onlinelibrary.wiley.com/doi/10.1111/jonm.12354/abstract

3. Bulechek GM, Butcher HK, Dochterman JM. NIC: Classificação das Intervenções de Enfermagem. Rio de Janeiro: Elsevier; 2016. 610p 
4. Perroca MG. The new version of a patient classification instrument: assessment of psychometric properties. J Adv Nurs [Internet]. 2013[cited 2016 Oct 15];69(8):1862-68. Available from: http://onlinelibrary.wiley.com/doi/10.1111/jan.12038/full

5. Sousa CA, Jerico MC, Perroca MG. Measurement of nurses' workload in an oncology outpatient clinic. Rev Esc Enferm USP [Internet] 2014[cited 2016 Oct 10];48(1):97-103. Available from: http://www.scielo.br/pdf/reeusp/v48n1/0080-6234-reeusp-48-01-97.pdf

6. Desjardins F, Cardinal L, Belzile E, McCusker J. Reorganizing nursing work on surgical units: a time-and-motion study. Nurs Leadersh [Internet]. 2008[cited 2016 Oct 15];21(3):26-38. Available from: http://www.longwoods.com/content/20057

7. Cornell P, Riordan M, Townsend-Gervis M, Mobley R. Barriers to critical thinking: workflow interruptions and task switching among nurses. J Nurs Adm [Internet]. 2011[cited 2016 Oct 15];41(10):407-14. Available from: https://www.ncbi.nlm.nih.gov/ pubmed/21934427

8. Cornell P, Herrin-Griffith D, Keim C, Petschonek S, Sanders AM, D 'Mello S, et al. Transforming nursing workflow, Part 1: the chaotic nature of nurse activities. J Nurs Adm [Internet]. 2010[cited 2016 Oct 15];40(9):366-73. Available from: http://journals. Iww.com/jonajournal/Abstract/2010/09000/Transforming_Nursing_Workflow,_Part_1_The_Chaotic.6.aspx

9. Jeong DJY, Kurcgant P. Fatores de insatisfação no trabalho segundo a percepção de enfermeiros de um hospital universitário. Rev Gaúcha Enferm [Internet]. 2010[cited 2016 Oct 15];31(4):655-61. Available from: http://www.scielo.br/pdf/rgenf/v31n4/ a07v31n4.pdf

10. Rauhala A, Fagerstrom L. Are nurses' assessments of their workload affected by non-patient factors? an analysis of the RAFAELA system. J Nurs Manag [Internet]. 2007[cited 2016 Oct 17];15:490-99. Available from: http://onlinelibrary.wiley.com/ doi/10.1111/j.1365-2834.2007.00645.x/abstract

11. Myny D, Hecke A, Bacquer D, Verhaegue S, Gobert M, Deflorr T, et al. Determining a set of measurable and relevant factors affecting nursing workload in the acute care hospital setting: a cross-sectional study. Int J Nurs Stud[Internet]. 2012 [cited 2016 Oct 15];49(4):427-36. Available from: http://www.journalofnursingstudies.com/article/S0020-7489\%2811\%2900402-0/abstract

12. Polit DF, Beck CT. Fundamentos de pesquisa em enfermagem: avaliação de evidencias para a prática de enfermagem. 7.ed. Porto Alegre: Artmed, 2011.

13. Myny D, Van Goubergen D, Gobert M, Vanderwee K, Van Hecke A, Defloor T. Non-direct patient care factors influencing nursing workload in acute care hospitals: an integrative review of the literature. J Adv Nurs [Internet]. 2011 [cited 2016 Oct 17];67(10):2109-29. Available from: http://onlinelibrary.wiley.com/doi/10.1111/j.1365-2648.2011.05689.x/abstract

14. Cordova PB, Lucero RJ, Hyun S, Quinlan P, Price K, Stone PW. Using the Nursing Interventions Classification as a potential measure of nurse workload. J Nurs Care Qual [Internet]. 2010[cited 2016 Oct 17];25(1):39-45. Available from: https://www.ncbi. nlm.nih.gov/pmc/articles/PMC2869293/

15. Cruz CWM, Bonfim D, Gaidzisnki RR, Fugulin FMT, Laus AM. The Use of Nursing Interventions Classification (NIC) in identifying the workload of nursing: an integrative review. Int J Nurs Knowl [Internet]. 2014[cited 2016 Oct 17];25(3):154-60. Available from: http://onlinelibrary.wiley.com/doi/10.1111/2047-3095.12031/abstract

16. Barnes RM. Estudo de tempos e movimentos: projeto e medida de trabalho. São Paulo: Edgard Blucher, 2001.

17. Catipon JB, Infante EJT. Time tracking technology [Internet]. 2012 [cited 2016 Oct 15]. Available from: http://www.google.com/ patents/US20120065932

18. Toggl. Insanely simple time tracking [Internet]. 2016[cited 2016 Oct 15]. Available from: https://www.toggl.com/

19. Chaboyer W, Wallis M, Duffield C, Courtney M, Seaton P, Holzhauser K, et al. A comparison of activities undertaken by enrolled and registered nurses on medical wards in Australia: an observational study. Int J Nurs Stud [Internet]. 2008 [cited 2016 Nov 20];45(9):1274-84. Available from: http://www.journalofnursingstudies.com/article/S0020-7489(07)00250-7/abstract

20. Bordin LC, Fugulin FMT. Nurses' time distribution: identification and analysis in a medical-surgical unit. Unidade MédicoCirúrgica. Rev Esc Enferm USP [Internet]. 2009[cited 2016 Nov 20];43(4):833-40. Available from: http://www.scielo.br/pdf/ reeusp/v43n4/en_a14v43n4.pdf

21. Soares AVN, Gaidzinski RP, Cirico MOV. Nursing intervention identification in rooming-in. Rev Esc Enferm USP [Internet]. 2010[cited 2016 Nov 20];44(2):307-16. Available from: http://www.scielo.br/pdf/reeusp/v44n2/en_10.pdf

22. Garcia EA, Fugulin FMT. Nurses' work time distribution at the emergency service. Rev Esc Enferm USP [Internet]. 2010 [cited 2016 Nov 20];44(4):1027-36. Available from: http://www.scielo.br/pdf/reeusp/v44n4/en_25.pdf

23. Broca PV, Ferreira MA. Characteristics of communication process in nursing team. Rev Enferm UFPE [Internet]. 2015[cited 2016 Nov 20];9(5):8428-36. Available from: http://www.revista.ufpe.br/revistaenfermagem/index.php/revista/article/view/6432/ pdf_8104

24. Gonçalves MI, Rocha PK, Anders JC, Kusahara DM, Tomazoni A. Communication and patient safety in the change-of-shift nursing report in neonatal intensive care units. Texto Contexto Enferm [Internet]. 2016[cited 2016 Nov 20];25(1):1-8. Available from: http://www.scielo.br/pdf/tce/v25n1/en_0104-0707-tce-25-01-2310014.pdf

25. Hendrich A, Chow MP, Skierczynski BA, Lu Z. A 36-hospital time and motion study: how do medical-surgical nurses spend their time? Perm J [Internet]. 2008[cited 2016 Nov 20];12(3):24-34. Available from: https://www.ncbi.nlm.nih.gov/pmc/articles/ PMC3037121/ 
26. Westbrook JI, Duffield C, Lil L, Creswick NJ. How much time do nurses have for patients? a longitudinal study quantifying hospital nurses' patterns of task time distribution and interactions with health professionals. BMC Health Serv Res [Internet]. 2011[cited 2016 Dec 15];11:319. Available from: http://bmchealthservres.biomedcentral.com/articles/10.1186/1472-6963-11-319

27. Rondina JM, Canêo PK, Campos MS. Conhecendo a experiência de implantação do prontuário eletrônico do paciente no hospital de base de São José do Rio Preto. Rev Adm Hosp Inov Saúde [Internet]. 2016[cited 2016 Dec 15];13(1):43-52. Available from: http://revistas.face.ufmg.br/index.php/rahis/article/view/43-52

28. Matsuda LM, Evora YDM, Higarashi IH, Gabriel CS, Inoue KC. Nursing informatics: unveiling the computer use by nurses. Texto Contexto Enferm[Internet]. 2015[cited 2016 Dec 22];24(1):178-86. Available from: http://www.scielo.br/pdf/tce/v24n1/01040707-tce-24-01-00178.pdf

29. Young J, Lee M, Sands LP, McComb S. Nursing activities and factors influential to nurse staffing decision-making. J Hosp Adm [Internet]. 2015[cited 2016 Dec 15];4(4):24-31. Available from: http://www.sciedu.ca/journal/index.php/jha/article/ view/6803/4197

30. Kalisch BJ, Aebersold M. Interruptions and multitasking in nursing care. Joint Comm J Qual Patient Saf [Internet]. 2010[cited 2016 Dec 15];36(3):126-32. Available from: https://www.researchgate.net/profile/Beatrice_Kalisch/publication/42253476 Interruptions_and_multitasking_in_nursing_care/links/004635140a7e5c0c14000000.pdf 